\title{
Balling's attenuation theory and beer composition calculator
}

\author{
Vilém Nohel \\ PMS Přerov a.s. - breweries Zubr, Litovel, Holba, \\ Komenského 35, 75002 Přerov, Czech Republic
}

*corresponding author: nohel@pivovary.cz

\begin{abstract}
This article deals with ways in which calculations and checks of basic parameters of beer can be performed based on the knowledge of two parameters. The importance of this method is growing with the increase in craft beer production in our country, i.e. mini breweries, home-brewing, etc. The calculations are based on Balling's equations, alcohol factors and attenuation quotients which have been published unchanged at least since 1876. In Balling's time, they were used to determine an extract with a specific gravity of $17.5^{\circ} \mathrm{C} / 17.5^{\circ} \mathrm{C}$. In current brewing, specific gravities of $20^{\circ} \mathrm{C} / 20^{\circ} \mathrm{C}$ are used. For this reason, new alcohol factors of apparent attenuation were derived and based on linear regression. Regression coefficients of the dependence of the alcohol factor of apparent attenuation on the extract in original wort were calculated. Some variants of calculations based on two input parameters were incorporated into the beer composition calculator using formulas that replace extract and alcohol tables. The accuracy of the results from the calculator was checked with analyses from the Anton Paar automatic analyser and with analyses obtained by the distillation method. The calculator is available at www.balling.cz.
\end{abstract}

Keywords: Balling's equations, alcohol factors, attenuation quotient, apparent attenuation, real attenuation, specific gravity, alcohol content, real extract, Tabarie's formula

\section{Introduction}

The basic parameters of beer include, but are not limited to: extract in original wort, apparent extract, real extract, real degree of fermentation, apparent degree of fermentation, alcohol content, specific gravities of beer, alcohol and real extract. In the case of industrial breweries, these values are usually obtained from an automatic analyser. From the perspective of craft beer production (mini-breweries, home-brewing), the purchase of an expensive device for determining the basic parameters of beer has no economic justification, and it is generally necessary to make do with a saccharometer for measurements with technology.

Professor Carl Napoleon Balling dealt with the fermentation processes of beer. Balling mathematically expressed the mass balance of wort during fermentation and experimentally verified it. This work brought him great recognition, and according to the relationships and formulas he derived, the original concentration of wort in the brewing industry is still calculated from the determined values of alcohol and the real extract of beer (Basařová et al., 2010).

While the derivation of large Balling's formula for the calculation of the extract in original wort on the basis of mass balance is mentioned in brewing literature, Balling's alcohol factors and formulas resulting from the theory of attenuation are virtually non-existent in brewing literature today. An article by Budweiser Budvar employees in the journal Kvasný průmysl (Šavel et al., 2015), and an article in the Journal of the Institute of Brewing (Cutaia et al., 2009), are recent exceptions.

\section{List of symbols \\ $p \quad$ extract in original wort OE (\% Plato, $\% \mathrm{~m} / \mathrm{m})$ \\ $A \quad$ alcohol A\%mas $(\% \mathrm{~m} / \mathrm{m}=\mathrm{g} / 100 \mathrm{~g})$ \\ $A \quad$ alcohol A\%vol (\% v/v $=\mathrm{ml} / 100 \mathrm{ml})$}


$m$ apparent extract AE $(\% \mathrm{~m} / \mathrm{m})$

$n$ real extract RE $(\% \mathrm{~m} / \mathrm{m})$

$S G_{B E E R} \quad$ specific gravity of beer

$S G_{A} \quad$ specific gravity of distillate

$S G_{E} \quad$ specific gravity of residue

$A D F \quad$ apparent degree of fermentation (\%)

$R D F \quad$ real degree of fermentation (\%)

$R D F_{A S B C}$ real degree of fermentation by ASBC (\%)

(ASBC American Society of Brewing Chemists)

energy energy value of beer (kcal/100 ml, kJ/100 ml)

$\rho \quad$ density of beer $\left(\mathrm{g} / \mathrm{cm}^{3}\right)$

$a, b, c \quad$ alcohol factors

$q \quad$ attenuation quotient

Note: Sentences and phrases in the following text written in italics in quotations marks indicate literal translation original text from historical literature.

\section{Balling's attenuation theory}

\subsection{Balling's formulas}

Balling considered the following basic quantities:

$\mathrm{p}$ - extract in original wort

A - alcohol content

$\mathrm{n}$ - real extract

$\mathrm{m}$ - apparent extract

The difference $(p-m)$ expresses the apparent attenuation, which is directly proportional to the amount of fermented extract, and thus the alcohol content. Assuming that $1 \% \mathrm{~m} / \mathrm{m}$ of the apparent attenuation is $a \%$ of alcohol, the following ratio applies:

$$
\frac{a}{1}=\frac{A}{(p-m)}
$$

from which

$$
a=\frac{A}{(p-m)}
$$

Value $a$ is called the alcohol factor of apparent attenuation. Its variable value can therefore be calculated from the known values of $A, p$ and $m$. If, on the other hand, the value of factor $a$ is known, we can calculate the alcoholic content $A$ at each stage of fermentation for the known $p$ and $m$ :

$$
A=(p-m) a
$$

From the ratio of apparent attenuation to the original extract, the apparent degree of fermentation $A D F$ is calculated from the following ratio:

$$
\frac{p}{(p-m)}=\frac{100}{A D F}
$$

so

$$
A D F=100 \frac{(p-m)}{p}
$$

We can also derive the alcohol content from the real attenuation $(p-n)$ :

$$
A=(p-n) b
$$

and from it the alcohol factor of real attenuation

$$
b=\frac{A}{(p-n)}
$$

and the real degree of fermentation

$$
R D F=100 \frac{(p-n)}{p}
$$

The apparent attenuation is always numerically greater than the real attenuation. By subtracting the real attenuation from the apparent attenuation, the attenuation difference is obtained:

$$
(p-m)-(p-n)=n-m
$$

If the $c$ amount of alcohol corresponding to $1 \% \mathrm{~m} / \mathrm{m}$ attenuation difference, and $A$ alcohol pertaining to the whole attenuation difference with respect to $100 \mathrm{~g}$ fermented wort, then

$$
\frac{c}{1}=\frac{A}{(n-m)}
$$

and from it

$$
\begin{aligned}
& c=\frac{A}{(n-m)} \\
& A=(n-m) c
\end{aligned}
$$

Factor $c$ is the alcohol factor of the attenuation difference.

Another significant value is the attenuation quotient $q$, defined as the ratio of apparent and real attenuation:

$$
q=\frac{(p-m)}{(p-n)}
$$

By dividing equations $2 \mathrm{a}$ and $2 \mathrm{~b}$, we get the following relation:

$$
\begin{aligned}
\frac{A}{A} & =\frac{(p-m) a}{(p-n) b} \\
\frac{b}{a} & =\frac{(p-m)}{(p-n)}=q \\
a & =\frac{b}{q}
\end{aligned}
$$


The alcohol factor of the attenuation difference $c$ can also be derived from equations $2 \mathrm{~b}$ and $2 \mathrm{c}$ :

$$
\begin{aligned}
A & =A \\
c(n-m) & =b(p-n) \\
c & =\frac{b(p-n)}{(n-m)} \\
c & =\frac{b(p-n)}{(n-m+p-p)} \\
c & =\frac{\frac{b(p-n)}{(p-n)}}{\frac{(p-m)-(p-n)}{(p-n)}} \\
c & =\frac{b}{(q-1)}
\end{aligned}
$$

From equation 4 we can derive a relation for calculating $p$ :

$$
\begin{aligned}
\frac{(p-m)}{(p-n)} & =q \\
p-m & =(p-n) q \\
p-m & =p q-n q \\
p-p q & =m-n q \\
p(1-q) & =m-n q \\
p & =\frac{(m-n q)}{(1-q)} \\
p & =\frac{(n q-m)}{(q-1)}
\end{aligned}
$$

or equation $7 \mathrm{~b}$ can be modified to:

$$
\begin{aligned}
p(1-q)+n q & =m \\
p(1-q)+n q-n & =m-n \\
-p(q-1)+n(q-1) & =m-n \\
p(q-1) & =n(q-1)-m+n \\
p & =n+\frac{(n-m)}{(q-1)}
\end{aligned}
$$

By combining equations $7 \mathrm{~d}$ (Balling's small formula) and 6, we receive a relation for calculating

\begin{tabular}{|c|c|c|c|c|}
\hline \multirow{4}{*}{$\begin{array}{c}2 \text { Püvolni siln } \\
\text { mladinky udinni } \\
\text { v stupnieh } \\
\text { saccharometru } \\
=\mathrm{p} \\
\end{array}$} & \multicolumn{3}{|c|}{3 Faktory líbové pro } & \multirow{3}{*}{$\begin{array}{c}{ }^{4} \text { Attenuačni } \\
\text { kvocient }\end{array}$} \\
\hline & ${ }^{*}$ zadánlivon & ${ }^{* *}$ skuteinou & \multirow{2}{*}{$\begin{array}{c}\text { **** at tenuaini } \\
\text { rozdil }\end{array}$} & \\
\hline & \multicolumn{2}{|c|}{${ }^{* * *} a$ t t e n u a c i } & & \\
\hline & $=a$ & $\therefore \mathrm{b}$ & $=0$ & $\therefore q$ \\
\hline $\begin{array}{r}6 \\
7 \\
8 \\
9 \\
10 \\
11 \\
12 \\
13 \\
14 \\
15 \\
16\end{array}$ & $\begin{array}{r}0.4073 \\
4091 \\
4110 \\
4129 \\
0.4148 \\
4167 \\
4187 \\
4206 \\
4226 \\
4246 \\
4267\end{array}$ & $\begin{array}{r}0.4993 \\
5020 \\
5047 \\
5074 \\
0.5102 \\
5130 \\
5158 \\
5187 \\
5215 \\
5245 \\
5274\end{array}$ & $\begin{array}{r}2 \cdot 2096 \\
2116 \\
2137 \\
2160 \\
2 \cdot 2184 \\
2209 \\
2234 \\
2262 \\
2290 \\
2319 \\
2350\end{array}$ & $\begin{array}{r}1 \cdot 226 \\
227 \\
228 \\
229 \\
1 \cdot 230 \\
231 \\
232 \\
233 \\
234 \\
235 \\
236\end{array}$ \\
\hline & & & & 12 \\
\hline
\end{tabular}
$p$ in the following form:

$$
\begin{aligned}
& p=\frac{(n-m)}{(q-1)}+n \quad \text { and } \quad c=\frac{b}{(q-1)} \\
& p=\frac{1}{(q-1)}(n-m)+n \text { and } \quad q-1=\frac{b}{c} \\
& p=\frac{c}{b}(n-m)+n
\end{aligned}
$$

By combining equations 7 a and 5 , a relation can be derived for calculating the real extract $n$ :

$$
\begin{aligned}
n q=p q-p+m & =p q-(p-m) \\
n & =p-\frac{(p-m)}{q} \\
n & =p-(p-m) \frac{\mathrm{a}}{b}
\end{aligned}
$$

"After many, many tests and calculations, Balling calculated the alcohol factors for each wort density from 5 to 30 degrees of saccharometer" (Suk, 1880).

Figure 1 shows a table of alcohol factors and attenuation quotients for the fermentation of worts with $6-16 \%$ (Schmelzer a Skvrna, 1877), and Figure 2 shows Balling's table for alcohol factors and attenuation quotients for fermentation of beer worts containing $6-30 \%$ of extract (Šula, 1898).

Figure 1 Alcohol factors and attenuation quotients of 6-16\% original wort from the book Stručné pivovarnictví (Schmelzer a Skvrna, 1877)

1 Table of alcohol factors and attenuation quotients for the fermentation of worts with 6-16 percent

The original wort extract given in degrees of saccharometer

2 The original wort extract given in degrees of saccharometer
3 Alcohol factors for ${ }^{*}$ apparent and ${ }^{* *}$ real ${ }^{* * *}$ attenuation, ${ }^{* * * *}$ attenuation difference 4 Attenuation quotient

Numerical values of alcohol factors are identical and appear subsequently in professional brewing literature up to the present, e.g. (Suk, 1880; Thausing, 1882; Lhotský, 1954; Bednář et al., 1967; Albl et al., 1990; Hardwick, 1995). In the publication STRUČNÉ PIVOVARNICTVÍ (Brewery industry briefly) from 1877, Schmelzer and Skvrna end their preface IN PRAGUE on the day of St. Lucie 1876, meaning that values of factors do not change at least from this year on. 


\begin{tabular}{|c|c|c|c|c|}
\hline \multicolumn{5}{|c|}{$\begin{array}{l}{ }^{1} \text { Tabulka Ballingova pro alkoholové faktory a attenuačni quotienty pro krašeni pirnich } \\
\text { mladin } 6-30 \% \text { extraktu obsahujicich. }\end{array}$} \\
\hline \multirow{3}{*}{$\begin{array}{l}2 \text { Procenta ex- } \\
\text { trakttu r pú- } \\
\text { rodui mladině }\end{array}$} & \multicolumn{3}{|c|}{3 Alkoholové faktory pro } & \multirow{3}{*}{$\begin{array}{l}4 \text { Quotient } \\
\text { attenuǎ̌ni } \\
\frac{p-m}{p-n} \\
\end{array}$} \\
\hline & \multicolumn{2}{|c|}{${ }^{*}$ attenuaci } & \multirow{2}{*}{$\begin{array}{c}{ }^{* * * *} \text { rozclíl } \\
\text { attenuační } \\
n-m\end{array}$} & \\
\hline & $\begin{array}{c}{ }^{*} \text { zdánlivon } \\
p-m\end{array}$ & $\left.\right|_{p-n} ^{* \text { skuteonou }}$ & & \\
\hline$=p$ & $=a$ & $! \quad b$ & $=c$ & $=q$ \\
\hline $\begin{array}{l}1 \\
2 \\
3 \\
4 \\
5 \\
6 \\
7 \\
5 \\
5 \\
5 \\
10 \\
11 \\
12 \\
13 \\
14 \\
15 \\
16 \\
17 \\
18 \\
19 \\
20 \\
21 \\
22 \\
23 \\
24 \\
25 \\
26 \\
27 \\
28 \\
29 \\
30\end{array}$ & $\begin{array}{r}0,3983 \\
0,4001 \\
18 \\
36 \\
54 \\
73 \\
91 \\
0,4110 \\
29 \\
48 \\
67 \\
87 \\
0,4206 \\
26 \\
46 \\
67 \\
88 \\
0,4309 \\
30 \\
51 \\
73 \\
95 \\
0,4417 \\
39 \\
62 \\
85 \\
0,4508 \\
32 \\
56 \\
80\end{array}$ & \begin{tabular}{|r}
0,4864 \\
89 \\
0,4915 \\
41 \\
67 \\
93 \\
0,5020 \\
47 \\
74 \\
0,5102 \\
30 \\
58 \\
87 \\
0,5215 \\
45 \\
74 \\
0,5304 \\
34 \\
65 \\
96 \\
0,5427 \\
58 \\
50 \\
0,5523 \\
55 \\
89 \\
0,5622 \\
56 \\
90 \\
0,5725
\end{tabular} & $\begin{array}{r}2,2010 \\
24 \\
41 \\
58 \\
76 \\
96 \\
2,2116 \\
37 \\
60 \\
84 \\
2,2209 \\
34 \\
62 \\
90 \\
90 \\
2,2319 \\
50 \\
81 \\
2,2414 \\
48 \\
83 \\
2,2519 \\
57 \\
95 \\
2,2636 \\
77 \\
2,2719 \\
63 \\
2,2808 \\
54 \\
2,2902\end{array}$ & $\begin{array}{r}1,221 \\
2 \\
3 \\
4 \\
4 \\
5 \\
6 \\
7 \\
8 \\
9 \\
9 \\
1,230 \\
1 \\
2 \\
3 \\
3 \\
4 \\
5 \\
6 \\
7 \\
8 \\
9 \\
1,240 \\
1 \\
2 \\
3 \\
4 \\
4 \\
5 \\
6 \\
7 \\
8 \\
9 \\
1,250\end{array}$ \\
\hline
\end{tabular}

Figure 2 Alcohol factors and attenuation quotients from the book Návod ku zkoušení surovin, produktů a odpadků pivovarnických, 1. díl Rozbory chemické (Ŝula, 1898)

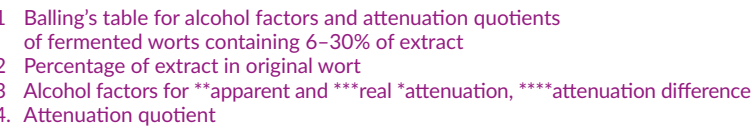

\subsection{Balling's saccharometric test}

Balling introduced a saccharometric test of beer in brewing based on the attenuation difference. "After removing carbonic acid from the beer by shaking in the bottle, the apparent extract $\mathrm{m}$ was determined with a saccharometer or pycnometer. Then, the beer is gradually boiled down to remove all the alcohol, which makes the beer lighter; after cooling, distilled water is added to get the beer to its original weight, and the real extract $\mathrm{n}$ is determined with a saccharometer or pycnometer" (Schmelzer and Skvrna, 1877). From the tabulated values of alcohol factors and attenuation quotients, and using equations $7 \mathrm{~d}$ and $2 \mathrm{c}$, "the extract in original wort and the amount of alcohol are determined".

With a pycnometer, the measured values "of relative weight" were found in Balling's extract table and "saccharometric data in percentages were subtracted" for $m$ and $n$ (see part of Balling's extract table in Figure 3).

"To make it easier to understand and calculate the extract in original wort and to determine the amount of alcohol", Balling created tables and guidelines for their use. Figure 4 shows the table "Determining the extract in original wort", where in the first column there is an attenuation difference ranging from 1.000 to 2.700 , and in the following six columns there are values $(n-m) /(q-1)$ for real attenuation $(p-n)$, "to which these differences in worts of 9-14\% of the mean extract content belong". When the extract in original wort is determined according to this table, it is possible to determine the amount of alcohol according to the table in Figure 5. In the first column there are attenuation differences, and the following six columns show "the amount of alcohol" corresponding to these attenuation differences at a "wort extract ranging from 8.51 to $14.50 \%$ ".

If the alcohol was determined directly by distillation, the extract in original wort was calculated according to Balling's large formula:

$$
p=100 \frac{(2.0665 A+n)}{(1.0665 A+100)}
$$

Balling's formula for calculating $p$ was gradually revised by Holzener, Schönfeld, Doemens and Trol (Lhotský, 1954). Recently, Scandinavian authors have commented on the validity of Balling's formula (Nielsen and Kristiansen, 2007, cited Šavel et al., 2015), and details of attempts to improve the model of Balling's original equation have been discussed (Cutaia et al., 2009). Due to its universality, the formula is a master tool for evaluating the production of alcohol under various conditions, and a revision would disrupt its universality; this will not even happen in the future due to the 150 years of practice (Šavel et al., 2015).

\subsection{Dependence of apparent attenuation on real attenuation}

It can be assumed that Balling performed most of his measurements using beers with the extract in original wort that were on the market and for which he developed "tables to determine the strength of the wort and the amount of alcohol" based on the attenuation difference (see above). " $10^{\circ}$ beer was most often brewed in breweries in Bohemia" (Šula, 1898). Based on these results, he then calculated the appropriate values for the entire range of the extract in original wort ranging from 1 to $30 \% \mathrm{~m} / \mathrm{m}$.

As can be seen from the calculations in Tables 1 and 2, there is a linear dependence between apparent and real attenuation. Table 1 shows the calculated values of apparent attenuation $(p-m)$ and real attenuation $(p-n)$ based on the use of Balling's alcohol factors $a$ a $b$ and quotients $q$ for extracts of the extract in orig- 
Table 1 Calculation of apparent extract and slope of the linear dependence of apparent attenuation on real attenuation for a specific gravity of $17.5^{\circ} \mathrm{C} / 17.5^{\circ} \mathrm{C}$

\begin{tabular}{|c|c|c|c|c|c|c|c|}
\hline \multicolumn{2}{|c|}{ Input date from table 4} & \multicolumn{3}{|c|}{$\begin{array}{c}\text { Balling's alcohol factors } \\
\text { and quotient q }\end{array}$} & \multicolumn{3}{|c|}{ Calculated value } \\
\hline \multirow{2}{*}{$p(\mathrm{OE})$} & \multirow{2}{*}{$n$ (RE) } & \multirow[t]{2}{*}{$a$} & \multirow{2}{*}{$b$} & \multirow{2}{*}{$q$} & \multirow{2}{*}{$m(\mathrm{AE})$} & $\begin{array}{l}\text { Apparent } \\
\text { attenuation }\end{array}$ & $\begin{array}{l}\text { Real } \\
\text { attenuation }\end{array}$ \\
\hline & & & & & & $(p-m)$ & $(p-n)$ \\
\hline 9 & 3.150 & 0.4129 & 0.5075 & 1.229 & 1.810 & 7.190 & 5.850 \\
\hline 10 & 3.500 & 0.4148 & 0.5102 & 1.230 & 2.004 & 7.996 & 6.500 \\
\hline 11 & 3.850 & 0.4167 & 0.5130 & 1.231 & 2.197 & 8.803 & 7.150 \\
\hline 12 & 4.200 & 0.4187 & 0.5159 & 1.232 & 2.390 & 9.610 & 7.800 \\
\hline 13 & 4.550 & 0.4206 & 0.5187 & 1.233 & 2.579 & 10.421 & 8.450 \\
\hline 14 & 4.900 & 0.4226 & 0.5216 & 1.234 & 2.768 & 11.232 & 9.100 \\
\hline \multirow{4}{*}{\multicolumn{5}{|c|}{$\begin{array}{l}r=\text { correlation coefficient } \\
\text { slope } \\
\text { intercept } \\
a=\text { angle of the line with the positive direction of the } x \text {-axis }\end{array}$}} & \multicolumn{3}{|c|}{$r=0.9999991$} \\
\hline & & & & & \multicolumn{3}{|c|}{ slope $=1.2436$} \\
\hline & & & & & \multicolumn{3}{|c|}{ intercept $=-0.0873$} \\
\hline & & & & & \multicolumn{3}{|c|}{$a=51^{\circ} 11^{\prime} 48^{\prime \prime}$} \\
\hline
\end{tabular}

inal wort ranging from 9 to $14 \% \mathrm{~m} / \mathrm{m}$ (real extracts $n$ at the real degree of fermentation $R D F=65 \%$ ). Table 2 shows calculated values of apparent and real attenuation for the whole range of the extract in original wort ranging from 1 to $30 \% \mathrm{~m} / \mathrm{m}$.

The apparent extracts $m$ were calculated from Balling's equation 4:

$$
\begin{aligned}
q & =\frac{(p-m)}{(p-n)} \\
m & =p-q(p-n)
\end{aligned}
$$

For the assumed measurement range for beers from 9 to $14 \% \mathrm{~m} / \mathrm{m}$, the slope is 1.2436 and the angle $\alpha$ (which forms a line with the positive direction of the $x$-axis) is $51^{\circ} 11^{\prime} 48^{\prime \prime}$.

For the whole range of the original wort extract from 1 to $30 \% \mathrm{~m} / \mathrm{m}$, the slope is 1.2511 and the angle $\alpha$ is $51^{\circ} 21^{\prime} 56^{\prime \prime}$. The difference between the angles of the two lines is minimal $\left(0^{\circ} 10^{\prime} 08^{\prime \prime}\right)$. In practice, it is a matter of finding a line that is as close as possible to the measured values. Balling apparently did the same.

\subsection{Calculation of Balling's alcohol factors}

They are currently used to determine the extract and alcohol with specific gravities of $20{ }^{\circ} \mathrm{C} / 20{ }^{\circ} \mathrm{C}$. However, in Balling's time they were used to determine the extract with specific gravities of $17.5^{\circ} \mathrm{C} / 17.5^{\circ} \mathrm{C}$ and to determine the alcohol content with specific gravities of $15{ }^{\circ} \mathrm{C} / 15{ }^{\circ} \mathrm{C}$ (Schmelzer and Skvrna,

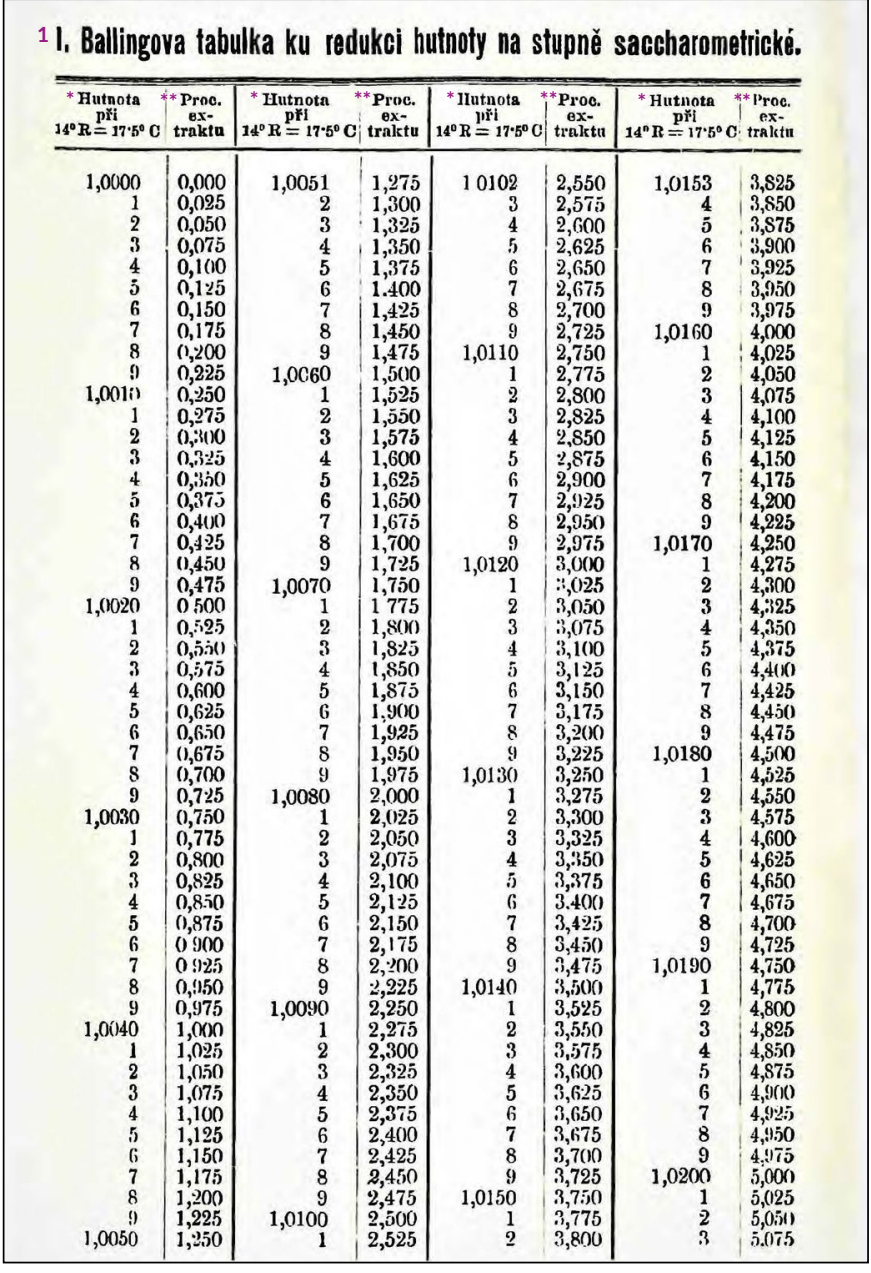

Figure 3 Title page of Balling's table for converting density to \% extract from the book Návod ku zkoušení surovin, produktů a odpadkü pivovarnických, 1. díl Rozbory chemické (Sula, 1898)

1 Balling's table of relative density reduction into saccharometric degrees *Relative density at, ${ }^{* *}$ Percentage of extract 
Table 2 Calculation of apparent extract and slope of the linear dependence of apparent attenuation on real attenuation for a specific gravity of $17.5^{\circ} \mathrm{C} / 17.5^{\circ} \mathrm{C}$

\begin{tabular}{|c|c|c|c|c|c|c|c|}
\hline \multicolumn{2}{|c|}{$\begin{array}{l}\text { Input date from } \\
\text { table } 4\end{array}$} & \multicolumn{3}{|c|}{$\begin{array}{c}\text { Balling's alcohol factors and } \\
\text { quotient q }\end{array}$} & \multicolumn{3}{|c|}{ Calculated value } \\
\hline \multirow[t]{2}{*}{$p(\mathrm{OE})$} & \multirow[t]{2}{*}{$n$ (RE) } & \multirow[t]{2}{*}{$a$} & \multirow[t]{2}{*}{$b$} & \multirow[t]{2}{*}{9} & \multirow[t]{2}{*}{$m(\mathrm{AE})$} & $\begin{array}{l}\text { Apparent } \\
\text { attenuation }\end{array}$ & $\begin{array}{l}\text { Real attenu- } \\
\text { ation }\end{array}$ \\
\hline & & & & & & $(p-m)$ & $(p-n)$ \\
\hline 1 & 0.350 & 0.3983 & 0.4864 & 1.221 & 0.206 & 0.794 & 0.650 \\
\hline 2 & 0.700 & 0.4001 & 0.4890 & 1.222 & 0.411 & 1.589 & 1.300 \\
\hline 3 & 1.050 & 0.4018 & 0.4915 & 1.223 & 0.615 & 2.385 & 1.950 \\
\hline 4 & 1.400 & 0.4036 & 0.4941 & 1.224 & 0.817 & 3.183 & 2.600 \\
\hline 5 & 1.750 & 0.4054 & 0.4967 & 1.225 & 1.018 & 3.982 & 3.250 \\
\hline 6 & 2.100 & 0.4073 & 0.4994 & 1.226 & 1.218 & 4.782 & 3.900 \\
\hline 7 & 2.450 & 0.4091 & 0.5020 & 1.227 & 1.416 & 5.584 & 4.550 \\
\hline 8 & 2.800 & 0.4110 & 0.5047 & 1.228 & 1.614 & 6.386 & 5.200 \\
\hline 9 & 3.150 & 0.4129 & 0.5075 & 1.229 & 1.810 & 7.190 & 5.850 \\
\hline 10 & 3.500 & 0.4148 & 0.5102 & 1.230 & 2.004 & 7.996 & 6.500 \\
\hline 11 & 3.850 & 0.4167 & 0.5130 & 1.231 & 2.197 & 8.803 & 7.150 \\
\hline 12 & 4.200 & 0.4187 & 0.5159 & 1.232 & 2.390 & 9.610 & 7.800 \\
\hline 13 & 4.550 & 0.4206 & 0.5187 & 1.233 & 2.579 & 10.421 & 8.450 \\
\hline 14 & 4.900 & 0.4226 & 0.5216 & 1.234 & 2.768 & 11.232 & 9.100 \\
\hline 15 & 5.250 & 0.4246 & 0.5245 & 1.235 & 2.956 & 12.044 & 9.750 \\
\hline 16 & 5.600 & 0.4267 & 0.5275 & 1.236 & 3.144 & 12.856 & 10.400 \\
\hline 17 & 5.950 & 0.4288 & 0.5304 & 1.237 & 3.331 & 13.669 & 11.050 \\
\hline 18 & 6.300 & 0.4309 & 0.5335 & 1.238 & 3.515 & 14.485 & 11.700 \\
\hline 19 & 6.650 & 0.4330 & 0.5365 & 1.239 & 3.697 & 15.303 & 12.350 \\
\hline 20 & 7.000 & 0.4351 & 0.5396 & 1.240 & 3.878 & 16.122 & 13.000 \\
\hline 21 & 7.350 & 0.4373 & 0.5427 & 1.241 & 4.059 & 16.941 & 13.650 \\
\hline 22 & 7.700 & 0.4395 & 0.5459 & 1.242 & 4.238 & 17.762 & 14.300 \\
\hline 23 & 8.050 & 0.4417 & 0.5491 & 1.243 & 4.415 & 18.585 & 14.950 \\
\hline 24 & 8.400 & 0.4439 & 0.5523 & 1.244 & 4.590 & 19.410 & 15.600 \\
\hline 25 & 8.750 & 0.4462 & 0.5556 & 1.245 & 4.766 & 20.234 & 16.250 \\
\hline 26 & 9.100 & 0.4485 & 0.5589 & 1.246 & 4.940 & 21.060 & 16.900 \\
\hline 27 & 9.450 & 0.4508 & 0.5623 & 1.247 & 5.111 & 21.889 & 17.550 \\
\hline 28 & 9.800 & 0.4532 & 0.5656 & 1.248 & 5.284 & 22.716 & 18.200 \\
\hline 29 & 10.150 & 0.4556 & 0.5691 & 1.249 & 5.455 & 23.545 & 18.850 \\
\hline 30 & 10.500 & 0.4580 & 0.5726 & 1.250 & 5.623 & 24.377 & 19.500 \\
\hline \multirow{4}{*}{\multicolumn{5}{|c|}{$\begin{array}{l}r=\text { correlation coefficient } \\
\text { slope } \\
\text { intercept } \\
a=\text { angle of the line with the }\end{array}$}} & \multicolumn{3}{|c|}{$r=0.99998$} \\
\hline & & & & & \multicolumn{3}{|c|}{ slope = 1.2511} \\
\hline & & & & & \multicolumn{3}{|c|}{ intercept $=-0.1074$} \\
\hline & & & & & \multicolumn{3}{|c|}{$a=51^{\circ} 21^{\prime} 56^{\prime \prime}$} \\
\hline
\end{tabular}

1877; Šula, 1898). For this reason, the use of Balling's alcohol factors of apparent attenuation a in the current brewing industry would not lead to completely accurate results.

For illustration, Table 3 shows values for specific gravities of $20^{\circ} \mathrm{C} / 20{ }^{\circ} \mathrm{C}$ and for specific gravities of $17.5^{\circ} \mathrm{C} / 17.5^{\circ} \mathrm{C}$ for the extract in original wort of $11 \%$ $\mathrm{m} / \mathrm{m}$ from the relevant tables and a real degree of fermentation of $65 \%$. To calculate the specific gravity of beer $17.5^{\circ} \mathrm{C} / 17.5^{\circ} \mathrm{C}$, the formula according to Tabarie was used, which was also used by Balling at the time (Šavel et al., 2015). An improved Tabarie's formula was used to calculate the specific gravity of beer at $20^{\circ} \mathrm{C} / 20{ }^{\circ} \mathrm{C}$ (Nielsen and Aastrup, 2004). 
Alcohol factors $a$ and $b$ were calculated according to equations $1 \mathrm{a}$ and $1 \mathrm{~b}$, and attenuation quotients $q$ according to equation 4 . For a specific gravity of $17.5^{\circ} \mathrm{C} / 17.5^{\circ} \mathrm{C}$, we obtain identical values of the alcohol factors $a, b$ and the attenuation quotient $q$ with the values derived by Balling.

Due to the different numerical values of the apparent extracts $m$, there will also be different numerical values of the quotients $q$. Since the alcohol factor of real attenuation $b$ is constant for a given $p$ (does not change with fermentation) and is equal to the product of $a q$ ( $a$ times $q$ ), the numerical values of alcohol factors $a$ will also vary.

To determine the alcohol factors for specific gravities of $20^{\circ} \mathrm{C} / 20^{\circ} \mathrm{C}$, calculations were performed in an EXCEL spreadsheet for each extract in original wort from 1 to $30 \% \mathrm{~m} / \mathrm{m}$ for real degree of fermentation 65\% (Table 4).

Calculation principle: formula $3 \mathrm{~b}$ for real fermentation was used to calculate the real extracts $n$, and Balling's large formula 10 was used to calculate the alcohol contents A\%mas.

The respective values of specific gravities were subtracted directly by interpolation from the tables used in the Anton Paar automatic analyzer. For the extract "the extract according to ASBC tables" (ASBC, 2020); for alcohol from the annex to the guidebook Alcolyzer Plus "Density and Concentration of Water/ Ethanol Solutions" (Anton Paar, (C 2007).

The specific gravities of beers were calculated according to the improved Tabarie's formula.

Tabarie's formula is as follows:

$$
S G_{B E E R}=S G_{E}+S G_{A}-1
$$

According to Scandinavian authors (Nielsen and Aastrup, 2004), the accuracy of Tabarie's formula is problematic - especially for strong beer. Based on many analyses of beer performed in Alfred Jørgensen's laboratory, an improved version of the old Tabarie's formula is proposed:

$S G_{B E E R}=S G_{E}+S G_{A}-1+2.96\left(1-S G_{A}\right)^{2}-381\left(1-S G_{A}\right)^{3}$

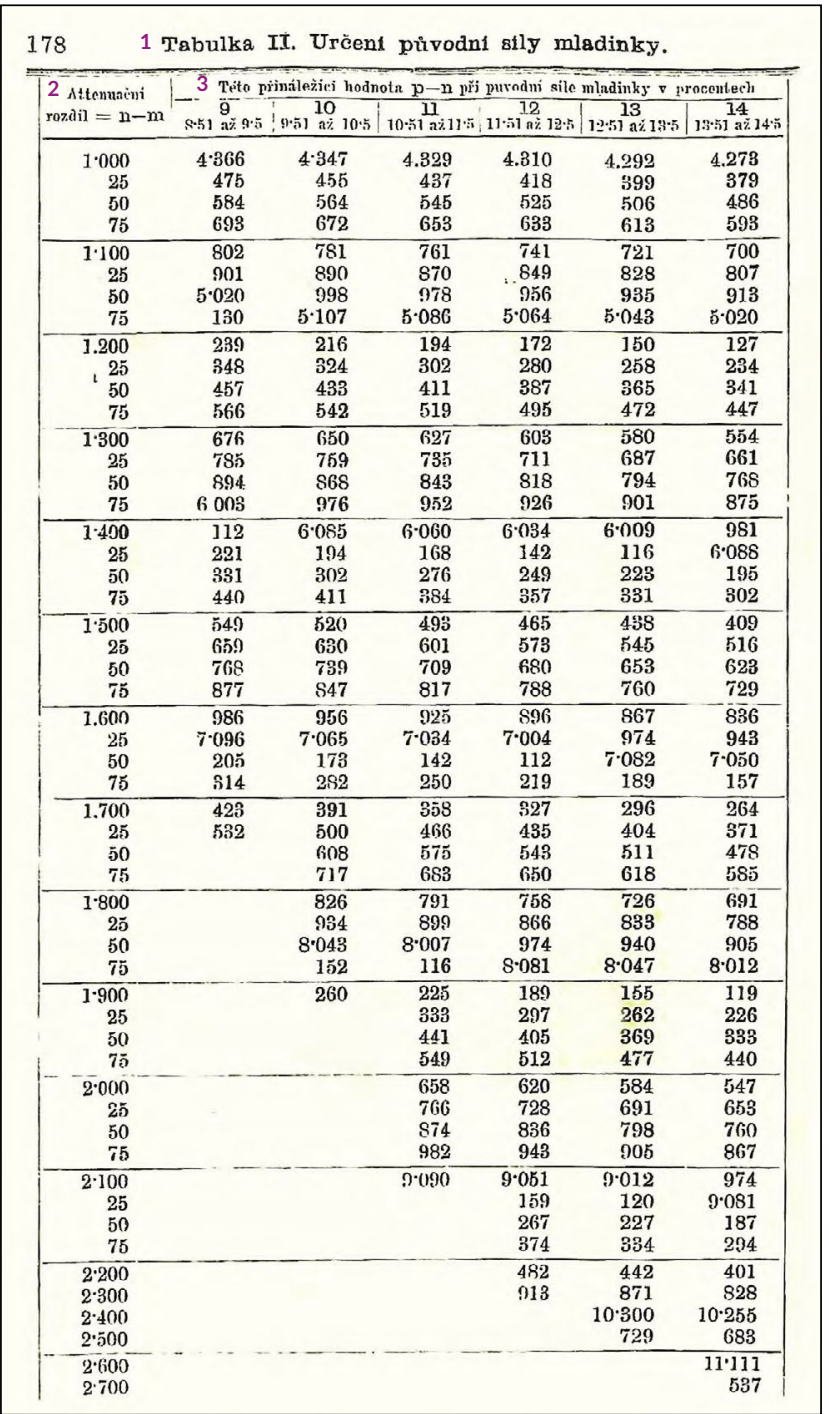

Figure 4 Table of determining the extract in original wort from the book Stručné pivovarnictví (Schmelzer a Skvrna, 1877)

1 Table II. Extract determination of original wort 2 Attenuation difference

This corresponds to the value $(p-n)$ of the original extract expressed as a percentage

While the old Tabarie's formula is less accurate for strong beer than for medium-strength beer, the improved version is valid for all beers up to $A \%$ mas $=8$, unless the degree of fermentation is extreme. The real degree of fermentation should be 65 to $85 \%$. Outside this range, accuracy has not been checked and increasing deviations can be expected (Nielsen and Aastrup, 2004).

Table 3 Alcohol factors and quotient q for $\mathrm{p}=11 \% \mathrm{~m} / \mathrm{m}$ and for specific gravities of $20^{\circ} \mathrm{C} / 20^{\circ} \mathrm{C}$ and $17.5^{\circ} \mathrm{C} / 17.5^{\circ} \mathrm{C}$

\begin{tabular}{|c|c|c|c|c|c|c|c|c|c|c|c|c|}
\hline Specific gravity & $p$ (OE) & RDF & $n(\mathrm{RE})$ & $S G_{E}$ & $A \%$ mas & $S_{A}$ & $S G_{\text {BEER }}$ & $m($ AE) & ADF & $a$ & $b$ & $q$ \\
\hline $20^{\circ} \mathrm{C} / 20^{\circ} \mathrm{C}$ & 11 & 65 & 3.85 & 1.01510 & 3.67 & 0.99337 & 1.00849 & 2.175 & 80.22 & 0.4157 & 0.5130 & 1.234 \\
\hline $17,5^{\circ} \mathrm{C} / 17,5^{\circ} \mathrm{C}$ & 11 & 65 & 3.85 & 1.01540 & 3.67 & 0.99338 & 1.00878 & 2.196 & 80.04 & 0.4166 & 0.5130 & 1.231 \\
\hline
\end{tabular}


Table 4 Calculation of Balling's alcohol factors and attenuation quotients of $1-30 \% \mathrm{~m} / \mathrm{m}$ original wort for a specific gravity of $20^{\circ} \mathrm{C} / 20^{\circ} \mathrm{C}$

\begin{tabular}{|c|c|c|c|c|c|c|c|c|c|c|c|c|c|}
\hline \multirow[b]{2}{*}{$p(\mathrm{OE})$} & \multirow[b]{2}{*}{ RDF } & \multirow[b]{2}{*}{$n$ (RE) } & \multirow[b]{2}{*}{$S G_{E}$} & \multirow[b]{2}{*}{$\begin{array}{l}A \%- \\
\text { mas }\end{array}$} & \multirow[b]{2}{*}{$S G_{A}$} & \multirow[b]{2}{*}{$S G_{B E E R}$} & \multirow[b]{2}{*}{$\underset{(\mathrm{AE})}{\mathrm{m}}$} & \multirow[b]{2}{*}{ ADF } & \multirow[b]{2}{*}{$a$} & \multirow[b]{2}{*}{$b$} & \multirow[b]{2}{*}{ c } & \multirow{2}{*}{$\frac{q}{\frac{b}{a}}$} & \multirow{2}{*}{$\frac{q}{\frac{(p-m)}{(p-n)}}$} \\
\hline & & & & & & & & & & & & & \\
\hline 1 & 65 & 0.350 & 1.00136 & 0.32 & 0.99939 & 1.00075 & 0.193 & 80.70 & 0.3918 & 0.4864 & 2.0138 & 1.242 & 1.242 \\
\hline 2 & 65 & 0.700 & 1.00273 & 0.64 & 0.99879 & 1.00152 & 0.391 & 80.46 & 0.3950 & 0.4890 & 2.0558 & 1.238 & 1.238 \\
\hline 3 & 65 & 1.050 & 1.00409 & 0.96 & 0.99818 & 1.00228 & 0.586 & 80.47 & 0.3970 & 0.4915 & 2.0648 & 1.238 & 1.238 \\
\hline 4 & 65 & 1.400 & 1.00546 & 1.28 & 0.99758 & 1.00304 & 0.780 & 80.49 & 0.3990 & 0.4941 & 2.0734 & 1.238 & 1.238 \\
\hline 5 & 65 & 1.750 & 1.00682 & 1.61 & 0.99697 & 1.00381 & 0.978 & 80.45 & 0.4013 & 0.4967 & 2.0901 & 1.238 & 1.238 \\
\hline 6 & 65 & 2.100 & 1.00819 & 1.95 & 0.99637 & 1.00458 & 1.175 & 80.41 & 0.4037 & 0.4994 & 2.1059 & 1.237 & 1.237 \\
\hline 7 & 65 & 2.450 & 1.00957 & 2.28 & 0.99577 & 1.00536 & 1.375 & 80.36 & 0.4061 & 0.5020 & 2.1242 & 1.236 & 1.236 \\
\hline 8 & 65 & 2.800 & 1.01095 & 2.62 & 0.99517 & 1.00614 & 1.575 & 80.31 & 0.4085 & 0.5047 & 2.1433 & 1.236 & 1.236 \\
\hline 9 & 65 & 3.150 & 1.01233 & 2.97 & 0.99457 & 1.00692 & 1.774 & 80.29 & 0.4109 & 0.5075 & 2.1578 & 1.235 & 1.235 \\
\hline 10 & 65 & 3.500 & 1.01371 & 3.32 & 0.99397 & 1.00770 & 1.973 & 80.27 & 0.4132 & 0.5102 & 2.1720 & 1.235 & 1.235 \\
\hline 11 & 65 & 3.850 & 1.01510 & 3.67 & 0.99337 & 1.00849 & 2.175 & 80.22 & 0.4157 & 0.5130 & 2.1905 & 1.234 & 1.234 \\
\hline 12 & 65 & 4.200 & 1.01649 & 4.02 & 0.99277 & 1.00927 & 2.374 & 80.22 & 0.4180 & 0.5159 & 2.2033 & 1.234 & 1.234 \\
\hline 13 & 65 & 4.550 & 1.01788 & 4.38 & 0.99217 & 1.01005 & 2.572 & 80.22 & 0.4203 & 0.5187 & 2.2159 & 1.234 & 1.234 \\
\hline 14 & 65 & 4.900 & 1.01928 & 4.75 & 0.99157 & 1.01083 & 2.771 & 80.21 & 0.4227 & 0.5216 & 2.2293 & 1.234 & 1.234 \\
\hline 15 & 65 & 5.250 & 1.02068 & 5.11 & 0.99097 & 1.01161 & 2.969 & 80.21 & 0.4251 & 0.5245 & 2.2416 & 1.234 & 1.234 \\
\hline 16 & 65 & 5.600 & 1.02208 & 5.49 & 0.99038 & 1.01239 & 3.166 & 80.21 & 0.4274 & 0.5275 & 2.2541 & 1.234 & 1.234 \\
\hline 17 & 65 & 5.950 & 1.02349 & 5.86 & 0.98978 & 1.01317 & 3.363 & 80.22 & 0.4298 & 0.5304 & 2.2659 & 1.234 & 1.234 \\
\hline 18 & 65 & 6.300 & 1.02490 & 6.24 & 0.98918 & 1.01394 & 3.558 & 80.23 & 0.4322 & 0.5335 & 2.2766 & 1.234 & 1.234 \\
\hline 19 & 65 & 6.650 & 1.02632 & 6.63 & 0.98858 & 1.01472 & 3.755 & 80.24 & 0.4346 & 0.5365 & 2.2886 & 1.234 & 1.234 \\
\hline 20 & 65 & 7.000 & 1.02773 & 7.01 & 0.98799 & 1.01549 & 3.949 & 80.26 & 0.4370 & 0.5396 & 2.2989 & 1.235 & 1.235 \\
\hline 21 & 65 & 7.350 & 1.02915 & 7.41 & 0.98739 & 1.01625 & 4.140 & 80.29 & 0.4394 & 0.5427 & 2.3079 & 1.235 & 1.235 \\
\hline 22 & 65 & 7.700 & 1.03058 & 7.81 & 0.98679 & 1.01701 & 4.331 & 80.31 & 0.4418 & 0.5459 & 2.3174 & 1.236 & 1.236 \\
\hline 23 & 65 & 8.050 & 1.03201 & 8.21 & 0.98619 & 1.01776 & 4.519 & 80.35 & 0.4442 & 0.5491 & 2.3251 & 1.236 & 1.236 \\
\hline 24 & 65 & 8.400 & 1.03344 & 8.62 & 0.98560 & 1.01851 & 4.708 & 80.39 & 0.4466 & 0.5523 & 2.3335 & 1.237 & 1.237 \\
\hline 25 & 65 & 8.750 & 1.03488 & 9.03 & 0.98500 & 1.01926 & 4.895 & 80.42 & 0.4491 & 0.5556 & 2.3422 & 1.237 & 1.237 \\
\hline 26 & 65 & 9.100 & 1.03631 & 9.45 & 0.98440 & 1.01999 & 5.078 & 80.47 & 0.4515 & 0.5589 & 2.3482 & 1.238 & 1.238 \\
\hline 27 & 65 & 9.450 & 1.03775 & 9.87 & 0.98378 & 1.02069 & 5.253 & 80.55 & 0.4537 & 0.5623 & 2.3509 & 1.239 & 1.239 \\
\hline 28 & 65 & 9.800 & 1.03920 & 10.29 & 0.98318 & 1.02141 & 5.433 & 80.60 & 0.4562 & 0.5656 & 2.3572 & 1.240 & 1.240 \\
\hline 29 & 65 & 10.150 & 1.04065 & 10.73 & 0.98258 & 1.02211 & 5.607 & 80.66 & 0.4586 & 0.5691 & 2.3615 & 1.241 & 1.241 \\
\hline 30 & 65 & 10.500 & 1.04210 & 11.16 & 0.98197 & 1.02281 & 5.781 & 80.73 & 0.4610 & 0.5726 & 2.3661 & 1.242 & 1.242 \\
\hline
\end{tabular}

According to our findings, the formula provides acceptable values of relative densities even for Czech beers (extract in original wort 10 to $12 \% \mathrm{~m} / \mathrm{m}$ ), which have a real degree of fermentation lower than $65 \%$.

Apparent degrees of fermentation were calculated according to formula $3 \mathrm{a}$.

Alcohol factors $a, b, c$ were calculated according to equations $1 \mathrm{a}, 1 \mathrm{~b}, 1 \mathrm{c}$, and the attenuation quotient $q$ was calculated according to equations 4 and 5 .

The dependence of alcohol factors $b$ on extracts in original wort $p$ was derived by combining equations $1 b$ and 10:

$$
b=\frac{A}{(p-n)}
$$

$A$ is determined from Balling's large formula:

$$
A=100 \frac{(p-n)}{(206.65-1.0665 p)}
$$

and introduced into the first equation:

$$
\begin{aligned}
& b=100 \frac{(p-n)}{(206.65-1.0665 p)(p-n)} \\
& b=\frac{1}{(2.0665-0.010665 p)}
\end{aligned}
$$

The dependence of alcohol factors $a$ on the extracts in original wort $p$ was derived on the basis of linear regression, because the correlation coefficient of the depend- 
Table 5 Regression equation of the depence of the alcohol faktor "a" on the original extract (1-30\% $\mathrm{m} / \mathrm{m})$ for a specific gravity of $20^{\circ} \mathrm{C} / 20^{\circ} \mathrm{C}$ : $\mathrm{a}=\mathrm{B}+\mathrm{M}^{*} \mathrm{p}$

\begin{tabular}{|c|c|c|c|}
\hline \multirow{2}{*}{ Alcohol factor } & \multicolumn{3}{|c|}{ Alcohol factor "a" from table 4} \\
\cline { 2 - 4 } & Correlation coefficient & \multicolumn{2}{|c|}{ Regression coefficients } \\
\hline$a$ & $r$ & $B$ & $M$ \\
\hline \multirow{2}{*}{$(-)$} & 0.99997 & 0.3895408891 & 0.002376648 \\
\cline { 2 - 4 } & & $a=0.389541+0.002377^{*} \mathrm{p}$ & \\
\hline
\end{tabular}

ence of $a$ on $p$ is significant ( $r=0.99997)$. Regression coefficients of the dependence of the alcohol factor $a$ on the extract in original wort $p$ were calculated (Table 5). The equation has the following form:

$$
a=0.389541+0.002377 p
$$

Table 6 shows calculations of the values of alcohol factors $a$ for $p=1$ to $30 \% \mathrm{~m} / \mathrm{m}$ according to regression equation 14 and comparisons with the values of alcohol factors $a$ calculated in Table 4 according to equation 1a. The differences are minimal, i.e. 0.0001 for the extract in original wort of Czech beers. Table 6 also shows values of apparent and real attenuation.

For the whole range of the extract in original wort ranging from 1 to $30 \% \mathrm{~m} / \mathrm{m}$, the slope of the dependence of apparent attenuation on real attenuation for specific gravities of $20^{\circ} \mathrm{C} / 20^{\circ} \mathrm{C}$ is 1.2393 , and the angle $\alpha$ is $51^{\circ} 05^{\prime}$ ' $56^{\prime \prime}$

The difference between the angle for $20^{\circ} \mathrm{C} / 20{ }^{\circ} \mathrm{C}$ specific gravities and the angle for $17.5^{\circ} \mathrm{C} / 17.5^{\circ} \mathrm{C}$ specific gravities (Table 2) is $00^{\circ} 16^{\prime} 00^{\prime \prime}$.

A graphic illustration is shown in Figure 6.

\section{Calculation of beer composition based on two input values}

Balling's attenuation theory shows the relationship between the basic parameters of beer cited in the introduction. If two parameters are known, the rest can be calculated.

For some calculation alternatives, a procedure was compiled where the individual variants of the input parameter pairs are in rows from $A$ to $M$, and the individual calculated beer parameters are in columns from 1 to 15. The listed calculations are incorporated into a spreadsheet, which we called the BEER COMPOSITION CALCULATOR (BCC). The calculator is available for practical use at www.balling.cz. In addition to the basic cited parameters, the calculation of alcohol factors $a$ and $b$, the attenuation quotient $q$, the real degree of fermentation $\mathrm{RDF}_{\mathrm{ASBC}^{\prime}}$ energy values $(\mathrm{kcal} / 100 \mathrm{ml}$ and $\mathrm{kJ} / 100 \mathrm{ml})$ and beer sample density $\left(\mathrm{g} / \mathrm{cm}^{3}\right)$ are added.
Extract and alcohol tables are replaced in the calculator by polynomial formulas. The formulas were taken from domestic (Šavel, 1989) and foreign literature (Cutaia et al., 2009).

Formulas for calculating alcohol $A \% \mathrm{vol}$, the real degree of fermentation according to ASBC, the energy

Figure 5 Table of determining the amount of alcohol from the book Stručné pivovarnictví (Schmelzer a Skvrna, 1877)

1 Table III. Determining of the ethanol content

Attenuation difference

Corresponding alcohol content at following values of the original wort extract 
value and the density of the beer sample were taken from the reference manual of Anton Paar (C) 2007). Other necessary calculation formulas are the subject of this article.

Calculated alcohol content in variant A (input $p$ and $m$ in craft beer production) based on equation 2a using the newly calculated alcohol factors $a$ for apparent attenuation at specific gravities of $20{ }^{\circ} \mathrm{C} / 20^{\circ} \mathrm{C}$ (Tables 4,5 and 6) can be compared with the calculated alcohol content according to formulas published in foreign literature.

Column 4a shows the calculation of alcohol content according to the following formula:

$A \%$ mas $=0.38726(O E-A E)+0.00307(O E-A E)^{2}$

(15) (Cutaia et al., 2009)

This equation was derived on the basis of a stepwise regression technique in order to find a more modern and accurate procedure for determining the prediction assumption of $A \%$ mas compared to Balling's equation $A=a(p-m)$. However, by comparing the results of the calculated alcohol contents from both formulas, i.e. from the BEER COMPOSITION CALCULATOR (variant A) and according to formula 15 , we find that we obtain virtually identical values (the difference for Czech beers depending on fermentation is +0.00 to $0.03 \% \mathrm{~m} / \mathrm{m}$ ) .

Similarly, in column 5 the calculation of the alcohol content $A \% v o l$ is according to "The Craft Formula":

$$
A \% \mathrm{vol}=\frac{(O E-A E)}{(2.048-0.01260 E)}
$$

(16) (Nielsen, 2004)

By comparing the results of the calculated alcohol contents from both formulas, i.e. from the BEER COMPOSITION CALCULATOR (variant A) and according to formula 16, we find a difference for Czech beers ranging from +0.04 to $0.07 \% \mathrm{v} / \mathrm{v}$. In general, formulas containing $\mathrm{A} \% \mathrm{vol}$ are less accurate than formulas containing $A \%$ mas.

Column $4 \mathrm{~b}$ shows the control calculation of the alcohol content according to formula $2 \mathrm{~b}$ (with the alcohol factor of the real attenuation $b$ ), the result must be identical to the result in column 4 a.

\section{Practical verification of beer calculator accuracy}

The accuracy of calculations according to the calculator was confronted with the results of analyses from Anton Paar analyzers from the database of breweries Zubr, Litovel and Holba according to variant $\mathrm{L}$ (input values $A \%$ mas and
$S G_{B E E R}$ ) for Czech beers with an extract in original wort of 10 to $12 \% \mathrm{~m} / \mathrm{m}$. The calculated values of $n$ and $p$ differed from the values found by the analyzers by 0.02 to $0.04 \% \mathrm{~m} / \mathrm{m}$.

From the results of analyses using the Anton Paar analyzer, we can calculate attenuation quotients $q$ as a share of apparent attenuation $(p-m)$ and real attenuation $(p-n)$. For Czech beers we get approximate values of 1.239. This corresponds to the calculated value of the slope of the apparent attenuation versus real attenuation for specific gravities of $20{ }^{\circ} \mathrm{C} / 20{ }^{\circ} \mathrm{C}$ and for a range of $p$ from 1 to $30 \% \mathrm{~m} / \mathrm{m}$ (Table 6 ).

Table 7 illustrates the results of analyses provided by RIBM (Research Institute of Brewing and Malting in Prague) from both the Anton Paar analyzer and the distillation method. Calculations are performed for both variants using the BEER COMPOSITION CALCULATOR. For comparison with the results from the Anton Paar analyzer, the input values are $A \%$ mas and $S G_{B E E R}$ (variant $\mathrm{L}$ ), and for comparison with the results of the distillation method, the input values are $S G_{E}$ and $S G_{A}$ (variant I). The difference found for the parameters $n$ and $p$ when the results from the beer composition calculator and the Anton Paar analyzer were compared (0.01 to $0.04 \% \mathrm{~m} / \mathrm{m}$ ) is given by different attenuation quotients $q$. Compared to the value $q=1.239$ from the Anton Paar analyzer, for each $p$ the calculator calculates the corresponding value of $q$; for Czech beers (extract in original wort 10 to $12 \% \mathrm{~m} / \mathrm{m}$ ) these values are 1.234 to 1.235 (Table 6).

\section{Practical use}

In recent years, several dozen new microbreweries have been put into operation in the Czech Republic every year, and there is also a growing unprecedented interest in homebrewing. In general, only a saccharometer 


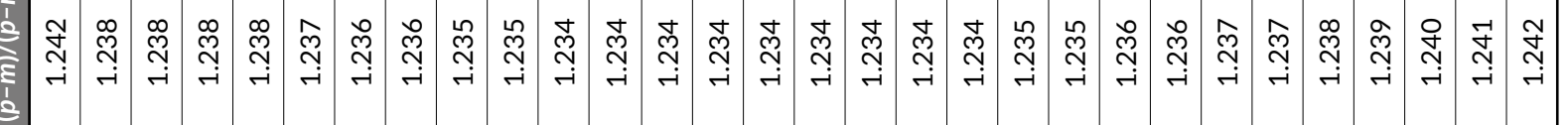

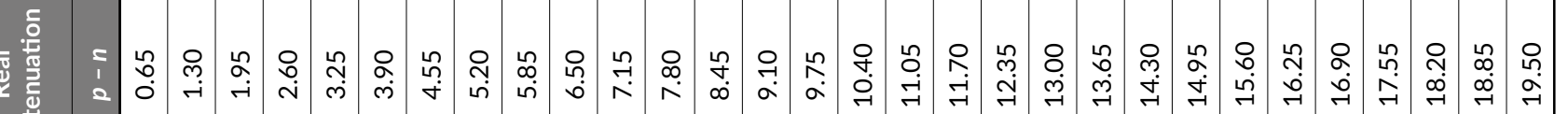

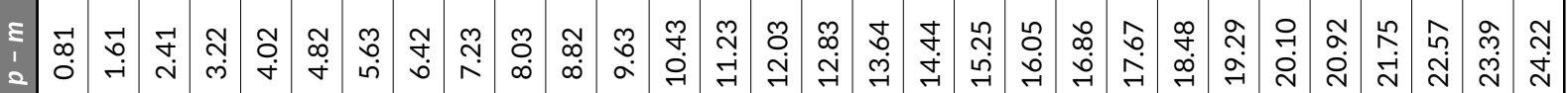

Е

বا

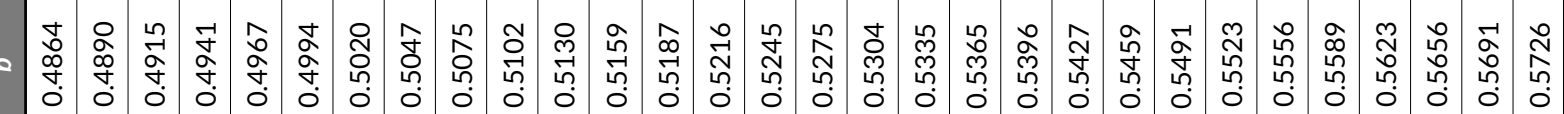

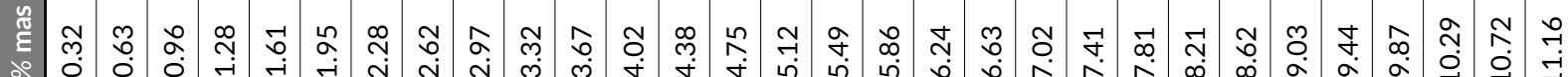

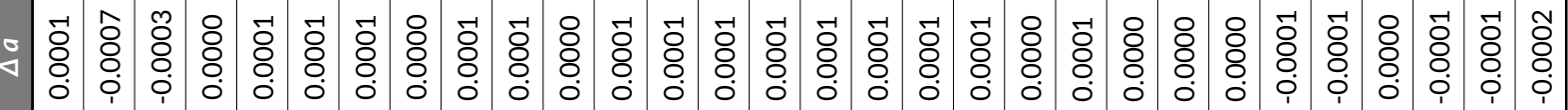

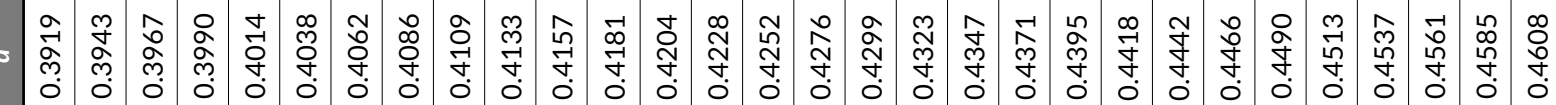

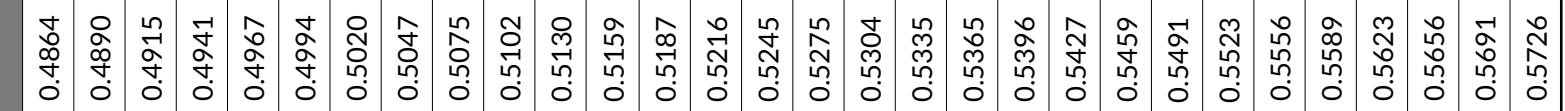

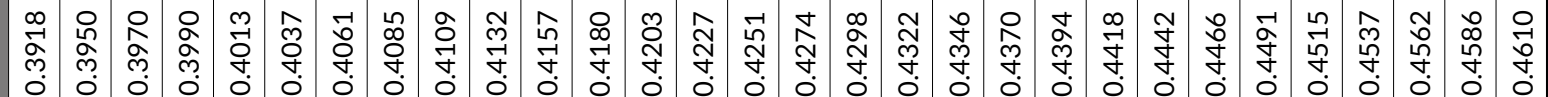

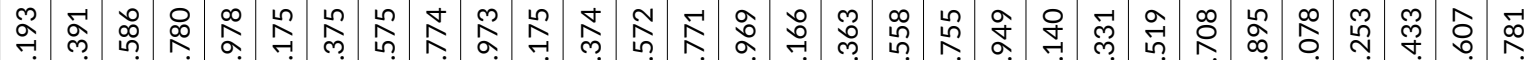

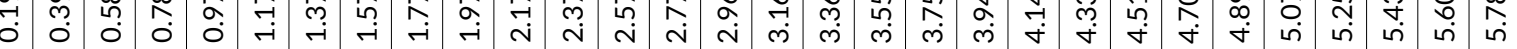

品 \& œ.

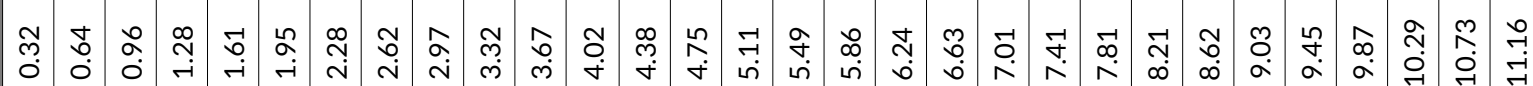


is used to check the technology. In cases where the final beer was prepared from one batch of wort, other beer parameters can be calculated based on the measurements of $p$ and $m$ (variant A).

Calculations using the beer composition calculator are very accurate. In order for the calculated beer parameters to correspond to reality, the input of the correct $p$ and $m$ values must be ensured. Based on experience from operational measurements in our research mini-brewery in the Litovel brewery, it is recommended to take into account the water with brewer's yeast for the parameter $p$, which is why the value found in the fermentation cellar is introduced immediately after pitching (not in the brewhouse). When measuring the apparent extract $m$ with a saccharometer, if the beer is not free of $\mathrm{CO}_{2}$ (this can also be ensured by manual shaking (Basařová, 1993)), the $\mathrm{CO}_{2}$ bubbles lighten the saccharometer, and this creates an error in comparison with the measurement in beer freed of $\mathrm{CO}_{2}$ by shaking after previous heating to a temperature close to $20^{\circ} \mathrm{C}$ (Hlaváček and Lhotský, 1972). Table 8 shows an example of deriving an acceptable correction for $\mathrm{CO}_{2}$ for the apparent extract when measured with a saccharometer $(0.2 \% \mathrm{~m} / \mathrm{m})$.

Variant $\mathrm{C}$ or D can be used to calculate the minimum and maximum values of beer parameters for individual groups (draught, lager) or tax zones (e.g. for $p=11.00$ to $11.99 \%$ $\mathrm{m} / \mathrm{m}$ ), which are required for audits of certified quality management systems. Brewing parametres, including fermentation, generally follow a normal (Gaussian) distribution. Using the mean $(\mu)$ and the standard deviation $(\sigma)$ in the interval $\mu \pm 3 \sigma$, we calculate the required limit values.

Variants G, H and I can be used in laboratories to check the accuracy of measuring three specific gravities $-S G_{E^{\prime}}$ $S G_{A}$ and $S G_{B E E R}$ - with a pycnometric distillation method.

\section{Conclusion}

Professor Balling excellently derived the theory of attenuation, which is of immense importance to brewing. His formula for calculating the extract in original wort from specified values of the real extract and alcohol in finished beer is used worldwide.

He introduced important quantities for the fermentation process such as apparent and real attenuation, apparent and real degree of fermentation, alcohol factors and the attenuation quotient.

Alcohol factors and attenuation quotients derived by Balling in the mid-19th century have been published unchanged since at least 1876. Specific gravities of $17.5^{\circ} \mathrm{C} / 17.5^{\circ} \mathrm{C}$ were used to determine the extract, and specific gravities of $15^{\circ} \mathrm{C} / 15^{\circ} \mathrm{C}$ were used to determine the alcohol content. Balling's small formula can be used to calculate the values of apparent extracts $m$ from the tabulated values of attenuation quotients $q$ for known values of the extract in original wort $p$ and the real extract $n$. For a range of $p$ from 1 to $30 \% \mathrm{~m} / \mathrm{m}$ and a specific gravity of $17.5^{\circ} \mathrm{C} / 17.5^{\circ} \mathrm{C}$, a linear dependence of the apparent attenuation on real attenuation ( $\mathrm{r}=0.99998)$, which is characterized by a slope of 1.2511 and an angle of $\alpha=51^{\circ} 21^{\prime} 56^{\prime \prime}$, can be deduced.

In today's brewing, the values of extract and alcohol are determined from specific gravities of $20^{\circ} \mathrm{C} / 20^{\circ} \mathrm{C}$. An improved Tabarie's formula was used to calculate the specific gravities of beer to determine the dependence of apparent attenuation on real attenuation. For a range of $p$ from 1 to $30 \% \mathrm{~m} / \mathrm{m}$, a linear dependence of the apparent attenuation on the real attenuation ( $r=0.999992)$, which is characterized by a slope of 1.2393 and an angle of $\alpha=51^{\circ} 05^{\prime} 56^{\prime \prime}$, was deduced.

The numerical difference of values of the slopes of both lines, or their angles $\left(0^{\circ} 16^{\prime} 0^{\prime \prime}\right)$, is due to different values of attenuation quotients $q$ (for different relative densities of $17.5^{\circ} \mathrm{C} / 17.5^{\circ} \mathrm{C}$ and $20^{\circ} \mathrm{C} / 20^{\circ} \mathrm{C}$ ) and alcohol factors of apparent attenuation $a$ for the given $p$, as the alcohol factor of real attenuation $b$ for the given $p$ is constant and equal to the product of $a q$ ( $a$ times $q$ ) (the $q$ changed, so the $a$ must also change so that their product remains the same).

To use Balling's alcohol factors in current brewing, new alcohol factors of apparent attenuation $a$ were calculated for a range of $p$ from 1 to $30 \% \mathrm{~m} / \mathrm{m}$. A formula was derived based on linear regression to calculate the alcohol factors $a$ :

$$
a=0.389541+0.002377 p
$$

Alcohol factors of real attenuation $b$ are derived from the equation $\mathrm{b}=A /(p-n)$, where a transformed Balling's large formula is introduced for $A[A=100(p-n) /(206.65$ $-1.0665 p)]$; after modification, the equation has the following form: $b=1 /(2.0665-0.010665 p)$

The calculated values of the alcohol factors of real attenuation $b$ are identical to the alcohol factors derived by Balling.

The spreadsheet contains some variants of beer composition calculations based on the inputs of two parameters (BEER COMPOSITION CALCULATOR). The calculator results can be exported in PDF format. The calculator can be used by practice of mini-breweries or home brewing to determine the composition of beer, in laboratories to check the accuracy of beer analysis by the reference (distillation) method and also in teaching in brewing schools. 


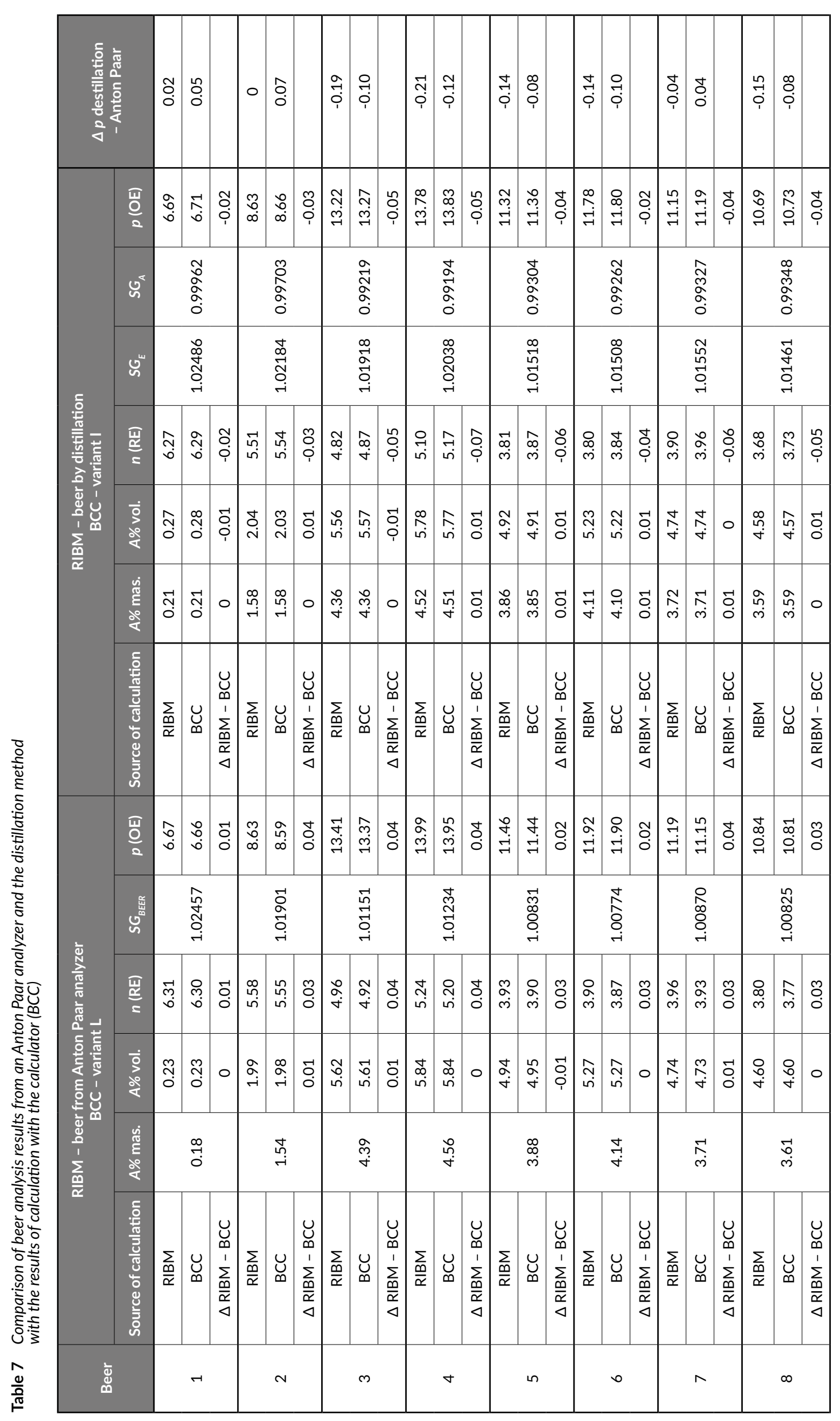


Table 8 Derivation of $\mathrm{CO}_{2}$ correction during operational measurement of apparent extract with a saccharometer $(\% \mathrm{~m} / \mathrm{m})$

\begin{tabular}{|c|c|c|c|}
\hline \multirow{2}{*}{ Sample number } & \multicolumn{2}{|c|}{ Measurement with a saccharometer } & C \\
\cline { 2 - 4 } & A & B & 2.56 \\
\hline 1 & 2.75 & 2.60 & 3.09 \\
\hline 2 & 3.25 & 3.10 & 2.95 \\
\hline 3 & 3.10 & 2.95 & 3.07 \\
\hline 4 & 3.30 & 3.00 & 2.86 \\
\hline 5 & 3.15 & 2.90 & 2.85 \\
\hline 6 & 3.10 & 2.85 & 2.62 \\
\hline 7 & 2.76 & 2.56 & 2.57 \\
\hline 8 & 2.72 & 2.51 & 2.82 \\
\hline average & 3.02 & 2.81 & \multirow{2}{*}{} \\
\hline$\Delta(\mathrm{A}-\mathrm{B}) \rightarrow$ & 0.21 & $\begin{array}{l}\text { A: operational measurement } \\
\text { B: beer sample from measurement A heated to } 20^{\circ} \mathrm{C} \text { and freed of } \mathrm{CO}_{2} \text { by shaking } \\
\text { C: beer from measurement B filtered through kieselguhr on filter paper }\end{array}$ \\
\hline$\Delta(\mathrm{A}-\mathrm{C}) \rightarrow$ & 0.19 & \multicolumn{2}{|}{}
\end{tabular}

\section{Acknowledgements}

The author of this article would like to thank Mrs. RNDr. Jana Olšovská, Ph.D. from RIBM Prague, for providing comparative analyses of beers performed on an Anton Paar analyzer and using the distillation method.

\section{References}

ASBC (2020). Tables Related to Determinations on Wort, Beer, and Brewing Sugars and Syrups [20.03.2020]. Available from: https://www.asbcnet.org/Methods/Tools/Tables/Documents/TableWortBeerBrewingSugars.pdf\#search=Determination $\% 20$ on $\% 20$ Wort $\% 2 \mathrm{C} \% 20$ Beer\%2C\%20and\%20Brewing\%20Sugars\%20and\%20Syrups

Anton Paar (C 2007). Reference Manual, Alcolyzer Plus Beer, Beer Analyzing System, Firmware Version: V5.01

Albl, V. (1990). Výroba piva a sladu pro učební obor biochemik-biochemička se zaměřením pro: výrobu piva a sladu (trans. Production of beer and malt for the field of study biochemist with a focus on: production of beer and malt). Institut výchovy a vzdělávání MZVž ČR v Praze, Prague, 363 pp. ISBN 80-7105-003-2. (Available only in Czech)

Basařová, G., Doležalová, A., Kahler, M., Čepička, J. (1993). Pivovarsko-sladařská analytika (trans. Brewing and malting analytics). Merkanta s.r.o., Prague, 966 pp. (Available only in Czech)

Basařová, G., Šavel, J., Basař, P., Lejsek, T. (2010). Pivovarství, Teorie a praxe výroby piva (trans. Brewing, Theory and practice of beer production). VŠCHT Praha, Prague, 863 pp. ISBN 978-80-7080-7347. (Available only in Czech)

Bednář, J., Štekr, K., Vančura, M. (1967). Pivovarsko-sladařské tabulky (trans. Brewing and malting tables). SNTL, Prague, 137 pp. (Available only in Czech)

Cutaia, A.J., Reid, A., Speers, R.A. (2009). Examination of the Relationship Between Original, Real and Apparent Extracts, and Alcohol in Pilot Plant and Commercially Produced Beers. J. Inst. Brew. 115 (4): 318-327.

Hardwick, W.A. (1995). Handbook of Brewing. Ed. Marcel Dekker Inc. New York, 714 s. ISBN 0-8247-8908-3.
Hlaváček, F., Lhotský, A. (1972). Pivovarství (trans. Brewing), 2. přepracované vydání, SNTL Prague, 539 pp. (Available only in Czech)

Lhotský, A. (1954). Technologie sladu a piva, 2. díl Výroba piva a strojní zařízení pivovarů, pomocné úkony (trans. Malt and beer technology, part 2 Beer production and brewery machinery, auxiliary operations. SNTL Prague, 423 pp. (Available only in Czech)

Nielsen, H., Aastrup, S. (2004). Improving Tabarié's Formula. Scandinavian Brewers' Rewiew, 61(4), 30-34.

Nielsen, H. (2004). New Formulas for sharp Calculations. World Brewing Congress2004, San Diego, California U.S.A.

Nielsen, H., Kristiansen, A.G., Lasen, K. M., Erikstrøm, C. (2007). Balling's formula - scrutiny of a brewing dogma. Brauwelt International, II,90-93. Available from: https://www.scribd.com/document/334496873/Balling-Formula-Scrutiny-of-a-Brewing-Dogma

Schmelzer, A.St., Skvrna F. (1877). Stručné pivovarnictví (trans. Brief Brewing). Redakce „Kvasu“, Prague, 223 pp. (Available only in Czech)

Suk, J.T. (1880). Nový Poupě (trans. The New Poupě), 1. díl. Slavík \& Borový, Prague, 254 pp. (Available only in Czech)

Šavel, J. (1989). Použití výpočetní techniky v pivovarských laboratořích (trans. Use of computer technology in brewing laboratories). Kvasny prumysl, 35(3), 69-71. Availailable in Czech from: https://www. kvasnyprumysl.cz/pdfs/kpr/1989/03/02.pdf

Šavel, J., Košin, P., Brož, A. (2015). Balling Alcohol Factors from the Perspective of Contemporary Brewing. Kvasny prumysl, 61(4), 120-128. https://doi.org/10.18832/kp2015015

Šula, J. (1898). Návod ku zkoušení surovin, produktů a odpadků pivovarnických, 1. díl Rozbory chemické. Podporou „Jednoty k založení a vydržování výzkumného ústavu pro průmysl pivovarnický v Čechách"(trans. Instructions for testing of raw materials, products and brewery waste, Part 1 Chemical analysis. With the support of the "Unity for the Establishment and Maintenance of the Research Institute of Brewing Industry in Bohemia". Nákladem vlastním (At my own expense), Prague, 336 pp. (Available only in Czech)

Thausing, J.E. (1882). Die Theorie und Praxis Malzberaitung und Bierfabrikation, 2. ed., J.M. Gebhardt`s Verlag, Leipzig, 880 pp. 